\title{
Pre-service Science Teachers' Perceptions toward Additional Instructional Strategies in Biology Laboratory Applications: Blended Learning
}

\author{
Yusuf Ziya Olpak', Huseyin Ates ${ }^{2 *}$ \\ ${ }^{1}$ Department of Computer Education and Instructional Technology, Ahi Evran University, Turkey, ${ }^{2}$ Department of Science Education, Ahi Evran \\ University, Turkey \\ *Corresponding author: huseyinates_38@hotmail.com
}

\section{ABSTRACT}

The purpose of this study was to examine pre-service science teachers' perceptions toward additional instructional strategies in biology laboratory applications in the scope of blended learning. This study used a mixed-methods sequential explanatory design model and was conducted with 69 students who study in their $2^{\text {nd }}$ year in the department of science education at a state university in Turkey. Academic achievement test, personal information form, student feedback form, semi-structured interview, and additional instructional strategies were used to collect the data. To determine students' academic achievements, the scores obtained from the academic achievement test were used from a pre-test and post-test and additional instructional strategies (discussion question, reflection paper, task assignment, and quiz) were used. In addition, students' views and satisfaction levels toward the course were examined. For data analysis, descriptive statistics, One-way ANOVA, and content analysis were used. The results of the study showed that students' academic achievement scores showed a significant difference in terms of the additional instructional strategies. In addition, students' evaluation scores and satisfaction levels about the learning process were high, but there was no significant difference in terms of additional instructional strategies. In the future, conducting similar studies with wider samples could be effective in terms of contributing to the relevant literature at different education levels and different disciplines.

KEY WORDS: academic achievement; additional instructional strategies; blended learning; satisfaction level; science education; student views

\section{INTRODUCTION}

D evelopments in information and communication technologies allow the amount of information produced to multiply day-by-day and allow people to attach importance to such developments in their daily lives and to apply them to their lives. Contribution of science and technology to the development of the educational process is big as in every field. Considering this point of view, during the acquisition, internalization, and transfer of knowledge, one concept that should be emphasized is distance education. Distance education includes interactive and educational processes between teacher and students apart from face-to-face education, which is not enough to meet al. students' needs (Harry et al., 1993). In addition, distance education has an interest in each learner's individual differences such as cognitive and learning styles, intellectual abilities, and personality features (Harry et al., 1993). One of the advantages of distance education, which support individual educational needs, is that internet technologies provide learners the opportunity to learn in any place they want at their own pace. As such, distance education has gained greater importance in all levels of education in recent years (Ding et al., 2010). Especially in higher education where structured class time per week and contact with the teacher has decreased, the reliance on self-regulated learning has increased (Broadbent, 2017). However, distance education has limitations, as students have reported feeling isolated by this learning environment, have encountered problems developing oral communication skills, and have communicated anxiety with other learners and teaching staff due to distance learning (Van Tryon and Bishop, 2009). Van Tryon and Bishop (2009) highlighted that distance education students need to be motivated, self-supervised, and self-disciplined.

\section{Blended Learning}

Even though distance education makes a great contribution to the education and training process, in some situations such as an unintelligible point, course evaluation or counseling, students need to communicate face-to-face with those who teach the course in a physical classroom. In such cases, distance learning alone is insufficient. Many studies stated that human engagement and social presence is important for successful learning (Geer, 2009; Kolowich, 2010). The best solution is to combine face-to-face education with technology-mediated instruction to provide instruction, and this kind of instruction is called "blended learning" (Garrison and Vaughan, 2008) which strengthen learning environments and increase student learning 
(Graham, 2006; Trpkovska, 2011). With blended learning, students could "take advantage of much of the flexibility and convenience of an online course while retaining the benefits of the face-to-face classroom experience" (Dziuban et al., 2011. p. 17). Blended learning also provides the following benefits: Reinforcement of students' efforts, the facilitation of cooperation of students, less dependence on teachers, more opportunities for learning, increased student satisfaction, provides new learning environments, greater cost-effectiveness, and improved access (Chen and Yao, 2016; Cheng and Chau, 2016; Gil and Garcia, 2011; Lorenzo and Moore, 2002). Since it provides both face-to-face and online learning possibilities together, a more active learning environment can be formed (Graham and Robinson, 2007) and students are provided with more access to resources, institutions, programs, and courses. Considering theoretical basics and paradigm shifts in blended education, using self-directed learning materials and management tools including feedback, blogs, e-portfolios, journals, online discussions, quizzes, and virtual lectures and activities have great importance (Lee et al., 2016).

\section{Science Education and Blended Learning}

Blended learning was adopted by many educational institutions to place a variety of learning styles in students for the purpose of offering flexible learning (Christensen and Evamy, 2011; Pelliccione and Broadley, 2010). In response, researchers in many educational areas have started to use it. Studies toward science education is among them, examples include laboratory experiences providing opportunities for students to improve their learning of scientific concepts; developing understanding to the nature and methods of science; improving the analytical and critical thinking skills, and increasing their interest to science (Basey et al., 2008; Ottander and Grelsson, 2006). At the same time, with the increasing demand toward blended learning, researchers have explored the possibility of using it in science education and developed innovative techniques (Leong, 2011; Rivera, 2016). Students studying at a distance can be connected to science educators using personal learning environments, social networking tools, course management systems, and other technologies (Mawn et al., 2011). Even though blended learning has great importance in science education, the related literature shows that the number of studies utilizing blended learning in science education is not very numerous (Bidarra and Rusman, 2017; Kuyatt and Baker, 2014; Olympiou and Zacharia, 2012). More importantly for this study's context, the Turkish science curriculum published in 2013 stated that understanding the importance of technology and using it is one of the purposes of science education and this topic is involved among four learning areas (MONE, 2013). Considering learning strategies in science education, technology-assisted investigation activities (Gröber et al., 2007) can be supposed as learning strategies which are embedded in blended learning (Lee et al., 2016).

The Council of Higher Education, which is responsible for the supervision of universities, determines the science education curriculum that is the same for all universities in Turkey. The science education curriculum includes physics, chemistry, and biology. Biology is taught in the $2^{\text {nd }}$ year of the universities and was the focus of this research. In the scope of this study, the face-to-face biology laboratory component of this study included those experiments determined by The Council of Higher Education: Investigating photosynthesis in plants, breeding living creatures in laboratory, comparing different tissue samples, detecting of carbohydrate, fats and protein in foods, investigating of blood cells, detecting blood groups, investigating embryonic developmental phases, observing respiration in living organisms, protists and tissues, and the factors affecting photosynthesis. Teaching at biology laboratory necessitates that pre-service science teachers (PSTs) carry out experiments interactively and this situation also necessitates peer instruction, peer assistance, and collaborative learning which support academic achievement (Broadbent, 2017).

Recent research has focused on the effort to develop students' academic performances by making them work more actively (Morice et al., 2015). Many studies showed that discussion and cooperation among peers was a positive influence on learning, based on a socio-constructivist approach to learning that plays an important role in social interaction in the course of knowledge (Dillenbourg et al., 1996). Social interaction based science education is not enabled only in the laboratory but also distance education allows students to interact with each other with additional instructional strategies in different learning environments such as discussion with peers in blog using web 2.0 tools, sharing documents, coconstructing wikis, and social networking (Luehmann and Frink, 2012) providing task assignment, preparing reflection paper, and weekly quizzes. These instructional strategies are important parts of this study in the scope of blended learning since studies related to this topic indicate successful findings in terms of students' learning (Burdina, 2011; Gholami and Moghaddam, 2013). Results of research conducted in higher education showed that there was a growing interest toward blended learning which contributed to students' learning and academic achievement and students, instructors, and institutions satisfaction (Çardak and Selvi, 2016; Marquis, 2004). In Marquis' (2004) study, the vast majority of instructors (94\%) expressed that this type of learning was much more effective than the traditional method. In a study conducted by Çardak and Selvi (2016), they studied 30 pre-service social studies teachers in Turkey and noted that students' interactions and levels of learning increased during the blended learning process.

\section{Purpose and Research Questions}

In the light of this information given above, the purpose of this study was to examine PSTs' perceptions toward additional instructional strategies in biology laboratory applications in the scope of blended learning. There were two research questions which guided this study.

1. How are students' academic achievement scores influenced by additional instructional strategies?

2. What are the students' views and satisfaction levels toward learning process? 
a. How well do students' evaluation scores toward learning process differ from the applied additional instructional strategies?

b. How well do students' satisfaction levels toward learning process differ from the applied additional instructional strategies?

\section{METHOD}

\section{Design of the Study and Participants}

In this study, the experimental design was carried out with 80 students registered in the "General Biology Laboratory II" course which was being taught in the department of science education in the faculty of education of a state university in Turkey. However, 11 students who did not attend regularly and/ or did not respond appropriately to the questions in the data collection tools used within the scope of the application were excluded from the study. Hence, all analyzes were performed on the data obtained from 69 students. In the process of grouping students, scores obtained from the academic achievement test were used as a pre-test. Four groups were formed and each group received different applications which are explained in detail under the application process topic: Discussion question - Group $1(n=14)$, task assignment - Group $2(n=20)$, quiz - Group $3(n=19)$, and reflection paper - Group $4(n=16)$. This study consisted of 14 males and 55 females who were assigned to groups randomly to control extraneous variables before the experiment began (Fraenkel et al., 2012). Mixedmethods sequential explanatory design was used in this study (Creswell et al., 2003).

\section{Data Collection Tools}

Within the scope of the research; the "student feedback form" and "personal information form" were used as data collection tools. To determine the academic achievements of the students, the scores obtained from academic achievement test used as a pre-test and post-test and additional instructional strategies (discussion question, reflection paper, task assignment, and quiz) were used. All of these have been created in accordance with the table of specifications prepared taking into account the objectives of the course. The prepared data collection tools were presented to five experts who specialized in blended learning on science education and Turkish language education for content validity, relevance to the students' level, rating, and effect on determining the academic achievement score. The recommended amendments were been made to the data collection tools based on the feedback from these experts. For example, some sentences were confusing and needed to be rewritten for better understanding. In the first version of the $28^{\text {th }}$ question in academic achievement test, the question was "If a diver suddenly emerges from the bottom of the sea to the surface, he/she can die of the bends. According to this, what should we do to not face this event?" However, after the revision, the definition of bends was obtained from Scott (2015) and added to the sentence. Consequently, the last version of the question is "The bends, also known as decompression sickness or Caisson disease occurs in scuba divers or high altitude or aerospace events when dissolved gases (mainly nitrogen) come out of solution in bubbles and can affect just about anybody area including joints, lung, heart, skin, and brain. If a diver suddenly emerges from the bottom of the sea to the surface, he/she can die of the bends. What should we do to not face this event?"

\section{Academic Achievement}

To determine the academic achievements of the students, students' final academic achievement scores were formed by calculating $60 \%$ of their post-test scores and $40 \%$ of the scores obtained from additional instructional strategies.

The achievement test was developed to determine the knowledge level of the students before the application and to measure the course successes after the application. For this purpose, a multiple choice test consisting of 41 questions was prepared. Item analysis in the test given in the final form in the direction of expert opinion was carried out with the participation of 161 students from a state university in Turkey who studied in the department of science education in a faculty of education and who had taken the course "General Biology Laboratory II." Items with discrimination indices which were $<0.30$ ( 11 items) were removed from the test, and multiple choice achievement test consisting of 30 questions was finalized. Three items with discrimination indices ranging from 0.21 to 0.26 were not removed from the test to ensure content validity since there were no other items for the relevant objectives. The KR-20 Reliability Coefficient of an achievement test, finalized, was calculated as 0.82 . The average item difficulty index in the test was 0.59 , while discrimination indexes of items in the achievement test vary between 0.21 and 0.70 .

\section{Feedback form and Semi-structured Interview}

A feedback form consisting of three open-ended questions was prepared to determine the students' views on the learning process. This form was implemented after expert opinions and feedback obtained from them were received. The prepared form was shared with the students at the end of the application process and students were asked about the items in the form. In addition to student feedback form, semi-structured interviews were carried out to determine students' views on the learning process after all applications were completed. Analysis obtained from both methods was performed by two experts who specialize in qualitative research methods.

\section{Application Process}

In this study, researchers followed the Garrison and Vaughan's (2008) "Learning Course Outline" including "Course Information," "Faculty Information Name," "Course Description (from the calendar)," "Textbook(s), Readings, and Course Materials," "Learning Outcomes," "Methods of Blended Learning Instruction," "Methods of Assessment," "Course Policies," and "Tentative Course Schedule and Related Readings" (p. 206). The application of the research was carried out over 10 weeks. The instructor, one of the researchers, provided feedback to the students about the activities during the application and guided them. 
At the beginning of the lesson, the instructor introduced himself to the students and shared his expectations about the lesson. Then, the webpage of the course was shown to students (http:// www.yzolpak.com/biology), and a preparation course was given to students to adapt to the online learning environment used in practice. During this brief process, the learning environment was introduced to the students, the technical and pedagogical information about the structure and use of the interaction tools was given, and effective and efficient usage suggestions were presented. It was also shown how they can create usernames and passwords to use during the study. Following these procedures, a multiple-choice achievement test was carried out to determine their pre-existing knowledge levels in the subject area. In the following week, courses were held face-to-face with students, and the grouping process was explained to the students. Students were given 3 days to examine the subject content and acquire familiarity with the learning environment. During the course of the application, it was also tried to ensure that the students had access to the instructor when needed.

During the application process, the students in Group 1 responded to the questions asked by the instructor about the topic each week using the blog in the online learning environment. Thus, they were able to examine the opinions of other students in the same group and reflect on their opinions. In this process, instructor also provided guidance and feedback by following the comments of the students. The students in Group 2 received task assignments 3 times related to the subjects taught during the application period and received feedback about their responses to these task assignments. Students in Group 3 took three quizzes about the course and received feedback on their answers to these questions. Finally, the students in Group 4 wrote a reflection paper on the topic taught each week after the course and received feedback from their reflection papers. In addition, students in all four groups received grades that would affect their academic achievement scores from these activities during the course. Two groups carried out their activities weekly, and two groups receive their application every 3 weeks. Grading of students' academic achievement scores was done in the light of the scores obtained from two experts in their field using a set rubric. To provide inter-rater reliability between experts, Cohen's kappa coefficient was calculated and found to be 0.85 .

In addition to the additional instructional strategies described above, the academic achievement test, which was the same as the pre-test, was applied to all the students as a final test, and the academic achievement scores were formed from the weighted average of the scores obtained. At the end of the application period, students' opinions were obtained by using student feedback form.

\section{Data Analysis}

In the analysis of the quantitative data obtained from the research, descriptive statistics and inferential statistics were used. Frequency, standard deviation, and mean were used for descriptive statistics, while One-Way ANOVA was performed for inferential statistics. Analysis of views expressed by the students through the feedback form constituted qualitative part of the study and was subjected to content analysis.

\section{Findings}

Examination of whether students' academic achievement scores significantly different in terms of groups: One-Way ANOVA was used to analyze whether the students' final academic achievement scores at the end of the application period differed significantly from the additional instructional strategy. Results of the analysis showed that there was a significant difference between the academic achievement scores of the students according to additional instructional strategy $\left(F_{(3,65)}=12.09, \rho<0.05\right)$. Findings toward this analysis are shown in Table 1.

The results of the Scheffe test showed that the different additional instructional strategy used in the learning process have different effects on students' academic achievement scores. The averages and standard deviation values of the students' academic achievement scores are given in Table 2.

As it is seen in Table 2, the average of the academic achievement scores of the students in different groups (1-4) according to the additional instructional strategy is 66.14 , 59.95, 78.79, and 72.50 .

\section{Students' Views and Satisfaction Level toward General Biology Laboratory II course}

"Student Feedback Form" was used to obtain students' views on the learning process. All 69 students in the study group filled out the feedback form including following questions.

1. How do you rate education in the scope of "General Biology Laboratory II" course if ranging from 1 (very bad) to 5 (very good)? By explaining the application, please state your opinions.

2. How do you rate your satisfaction level in the scope of "General Biology Laboratory II" course if ranging from

\begin{tabular}{|c|c|c|c|c|c|}
\hline $\begin{array}{l}\text { Source of } \\
\text { variation }\end{array}$ & $\begin{array}{l}\text { Sum of } \\
\text { squares }\end{array}$ & $\mathrm{df}$ & $\begin{array}{l}\text { Mean } \\
\text { square }\end{array}$ & $F$ & $\rho$ \\
\hline Between groups & 3762.79 & 3 & 1254.26 & 12.09 & 0.000 \\
\hline Within groups & 6743.82 & 65 & 103.75 & & \\
\hline Total & 10506.61 & 68 & & & \\
\hline
\end{tabular}

\begin{tabular}{|c|c|c|c|}
\hline Groups & $\mathbf{N}$ & $\bar{X}$ & SD \\
\hline Group 1 & 14 & 66.14 & 10.93 \\
\hline Group 2 & 20 & 59.95 & 14.09 \\
\hline Group 3 & 19 & 78.79 & 5.74 \\
\hline Group 4 & 16 & 72.50 & 7.41 \\
\hline Total & 69 & 69.30 & 12.43 \\
\hline
\end{tabular}


1 to 5? By explaining the application, please state your opinions.

3. Please specify that you want to add your comments and suggestions, if any.

Questions in feedback form consist of three questions evaluated as quantitative and qualitative. First, quantitative findings and then qualitative findings are presented with appropriate statistical analysis under different headings.

\section{Students' evaluations of general biology laboratory II course}

Quantitative findings presented under this heading are explained in two parts. First, students' views on "General Biology Laboratory II" course were explained with frequency and mean. Second, One-way ANOVA was used to examine whether the students' views on education differed significantly from the additional instructional strategy. Students' views on "General Biology Laboratory II" course can be listed as follows.

Twelve of the students in Group $1(n=14)$ said that the educational process they attend was very good or good. The number of students who indicated that their education was moderate and very bad was one for each. As a result of the obtained data, the average of the evaluation scores of the students in Group 1 was 4.14.17 students in Group 2 thought that blended learning was very good or good, while only three students evaluated as moderate. The average of the evaluation scores of the students in Group 2 was 4.15. All students $(n=19)$ in the Group 3 expressed evaluation of educational process as very good or good. Average evaluation score in Group 3 was 4.32. Similarly, all students $(n=16)$ in the Group 4 thought that "General Biology Laboratory II" course was very good or good. The average of the evaluation scores of the students in Group 4 was 4.50. The result of the One-way ANOVA showed that students' views on education were not differed significantly from the additional instructional strategy $\left(F_{(3,}\right.$ ${ }_{65)}=.936, p>0.05$ ).

\section{Students' satisfaction level toward general biology laboratory II course}

The findings presented under this heading are explained in two parts. First, students' satisfaction level toward "General Biology Laboratory II" course was explained with frequency and mean. Second, One-way ANOVA was used to examine whether the satisfaction level toward "General Biology Laboratory II" course differed significantly from the additional instructional strategy. It can be said that the students in the four different groups had a high level of satisfaction with their education. When satisfaction level of the students was examined; it was seen that the average scores in Group 2 were the lowest (4.40), while the average scores of the students in Group 4 were the highest (4.56). Result of the One-way ANOVA showed that students' satisfaction level toward "General Biology Laboratory II" course was not differed significantly from the additional instructional strategy $\left(F_{(3-65)}=0.253, P>0.05\right)$.
Scores toward students' views and satisfaction levels on "General Biology Laboratory II" course are indicated in Table 3.

\section{Students' views, satisfaction levels and suggestions toward general biology laboratory II course}

Data obtained from feedback form and semi-structured interview analysis and related findings were placed in this section. Obtained findings from content analysis were presented as a whole in terms of positive and negative statements, and following findings were reached. Positive views related to the course can be summarized as the aims and topics of the course are clearly defined and always accessible through the web page, indicating how to effectively and appropriately attend the classes, specification of time parameters and deadlines for course events, monitoring continued success and development, giving feedback, and having a different experience, an interesting lesson, and useful applications. The vast majority of students stated that they did not face any negative situations about the course. However, they emphasized the negative side of application as that internet connection was necessary to access the course activities and lack of time for experiments. In more detail, students who searched and prepared discussion questions and who prepared task assignment emphasized that they took the opportunity to follow their self-development in terms of some aspect such as encouraging research, learning scientific research methods, provisioning classroom

\begin{tabular}{|c|c|c|c|}
\hline Groups & Range & $F$ (views) & $\begin{array}{c}\text { F (satisfaction } \\
\text { level) }\end{array}$ \\
\hline \multirow[t]{6}{*}{ Group 1} & 5 & 6 & 8 \\
\hline & 4 & 6 & 5 \\
\hline & 3 & 1 & - \\
\hline & 2 & - & 1 \\
\hline & 1 & 1 & - \\
\hline & & $14(\mathrm{M}=4.14)$ & $14(\mathrm{M}=4.50)$ \\
\hline \multirow[t]{6}{*}{ Group 2} & 5 & 6 & 9 \\
\hline & 4 & 11 & 10 \\
\hline & 3 & 3 & 1 \\
\hline & 2 & - & - \\
\hline & 1 & - & - \\
\hline & & $20(\mathrm{M}=4.15)$ & $20(\mathrm{M}=4.40)$ \\
\hline \multirow[t]{6}{*}{ Group 3} & 5 & 6 & 11 \\
\hline & 4 & 13 & 7 \\
\hline & 3 & - & 1 \\
\hline & 2 & - & - \\
\hline & 1 & - & - \\
\hline & & $19(\mathrm{M}=4.32)$ & $19(\mathrm{M}=4.45)$ \\
\hline \multirow[t]{6}{*}{ Group 4} & 5 & 8 & 9 \\
\hline & 4 & 8 & 7 \\
\hline & 3 & - & - \\
\hline & 2 & - & - \\
\hline & 1 & - & - \\
\hline & & $16(\mathrm{M}=4.50)$ & $16(\mathrm{M}=4.56)$ \\
\hline
\end{tabular}


interaction, and developing their scientific process skills and discussion skills. Similarly, students in quiz application stated that this application regularly motivated them to study and increased their attendance to class and this situation lead to an increase in academic achievement. Students who wrote reflection paper emphasized that since they carried out this application every week, they needed to attend the course and listen to instructor carefully. They also said that they felt happy because they had an opportunity to evaluate and express their opinions related to the course.

\section{CONCLUSION AND DISCUSSION}

In this study, PSTs' perceptions toward additional instructional strategies in biology laboratory applications in the scope of blended learning were investigated. The results of the study showed that academic achievement scores of the students show a significant difference in terms of the additional instructional strategies. Accordingly, using different instructional strategies influenced the students' academic achievement. Especially, the students who were quizzed every 3 weeks and those who wrote a reflection paper each week showed higher success, while the discussion groups who answered instructor questions using blog with peers and those students in the task assignment group who conducted investigations related to course content given by instructor every 3 weeks underachieved. It is important to note here that the evaluation of the academic achievement of the two successful groups did not require an internet connection, but the internet connection was needed every week for the discussion group and every 3 weeks for the task assignment group. When on campus, they had the opportunity to connect to the internet and access thousands of databases using the university's internet network, however, when they were off campus, computing resources may not have been available. This negative situation actually was reported in a semi-structured interview. Students stated that an internet connection was necessary to access the course activities. In fact, in similar research, it was also stated that the lack of internet connection as a major disadvantage of distance education (Harris and Rea, 2009; Van Tryon and Bishop, 2009). However, in studies using a blog it was noted that this made a significant contribution to science education (Luehmann and Tinelli, 2008). Luehmann and Tinelli (2008) stated "in what ways blogging provide opportunities for social interaction that supported professional learning among practicing science teachers" using blog contents and it was obtained that it has benefits of "personal professional blogging" and "various types of cognitive, emotional, and social work participants collaboratively engaged in through blogging" (p. 55).

A weekly quiz, among additional instructional strategies, was another important element for students' academic achievement in this study. It was seen from the interviews with students that their interest in the course increased because of the quizzes. This result is supported in the literature (Gholami and Moghaddam, 2013; Zarei, 2008). In Zarei's (2008) study, quiz application supplied the students with motivation to attend classes. In Wilder et al. (2001) study, when the quizzes were carried out, student attendance increased by $10 \%$. However, some studies do not support our findings. For example, Haberyan (2013) investigated whether weekly quizzes improve student performance on general biology exams. He taught two sections of college-level general biology using experimental groups (quizzed) and control groups (unquizzed) and found that weekly quizzes were not an effective way to improve student performance. The reason why any significant findings cannot obtained could be that questions in the quizzes included both lecture and lab content. Nevertheless, most students in this study preferred having weekly quizzes and felt better able to keep up with their studies.

In the semi-structured interviews, students stated that they were pleased with the reflection paper application and it should be used in other courses as well. Our study's results showed that there was an increase in this group's student academic achievement. Burdina's (2011) study, confirms positive outputs from students using reflection papers. For example, in this study's this application increased students' motivation to study the course and students evaluated the course as entertaining, helpful, important, informing, interesting, and useful.

One more reason why this study was perceived by students as successful and useful was how they perceived the blended learning process and the prompt elaborated feedback that was given. When the relevant literature is examined, feedback is emphasized as one of the most useful methods to contribute to the learning of students (Hattie and Gan, 2011; James and Folorunso, 2012). In addition, Van der Kleij et al. (2015) meta-analysis study revealed that feedback was effective for students' academic achievement and especially elaborated feedback was more effective than feedback regarding the correctness of the answer and providing the correct answer for higher order learning outcomes.

Although we obtained useful findings from this application, there are some limitations in the present study. First, accessing internet connection can be a problem for students, especially applications in discussion questions that require active participation and internet connection using a weekly blog. Thus, some students could not complete all components of the study and accordingly, the number of the students was lower than others. In addition, plagiarism, especially for contributing to a discussion using a blog and completing related task assignments, may lead to controversial results. Since each student in this study had a username and password, it was not easy for web resources to be vandalized or damaged, even when a person tried to access the sources or discussions out of class time which has been seen as a problem in some distance education (Harris and Rea, 2009). In the future studies, researchers can also use this security application to resolve this kind of problem they can face. In addition, to prevent plagiarism academic plagiarism detectors such as Turnitin and iThenticate can be useful. During the application process, we used many online sources related to the course. However, the 
time required for the course may not be enough, so researchers could extend the time allocated for the course, especially during face-to-face learning.

For the future studies, it would be more useful if research determines how students' motivation changed toward the course after all the applications were completed and the relationship between motivation and academic achievement was investigated. Another potential research area concerns the grouping of students. Assigning students to groups using their learning approaches such as deep approach and surface approach would make a big contribution to the quality of the study. This is because students who practice a deep approach seek to understand what is in a more comprehensive context and integrate knowledge with prior knowledge, while students who practice a surface approach often concentrate on the learning of piecemeal knowledge and basically try to cope with their work (Chin and Brown, 2000; Entwistle and Peterson, 2004). Finally, conducting similar studies with wider samples, at different education levels, and different disciplines would be beneficial in terms of contributing to the relevant literature.

\section{ACKNOWLEDGMENTS}

A part of this study was presented as oral presentation in 'II. International Congress Students Engagement in School: Perspectives of Psychology and Education - Motivation for Academic Performance' hold in Lisbon/Portugal between 11 and 13 of July 2016.

\section{REFERENCES}

Basey, J., Sackett, L., \& Robinsons, N. (2008). Optimal science lab design: Impacts of various components of lab design on students' attitudes toward lab. International Journal for the Scholarship of Teaching and Learning, 2(1), 1-15.

Bidarra, J., \& Rusman, E. (2017). Towards a pedagogical model for science education: Bridging educational contexts through a blended learning approach. Open Learning: The Journal of Open, Distance and e-learning, 32(1), 6-20.

Broadbent, J. (2017). Comparing online and blended learner's self-regulated learning strategies and academic performance. The Internet and Higher Education, 33, 24-32.

Burdina, S. (2011). The Impact of Reflection Papers on Forming Students' Identity as Future Teachers in the Course "Theoretical Grammar". Available from: http://web.ceu.hu/crc/sotl_fel/Burdina_final.pdf

Chen, W.S., \& Yao, A.Y.T. (2016). An empirical evaluation of critical factors influencing learner satisfaction in blended learning: A pilot study. Universal Journal of Educational Research, 4(7), 1667-1671.

Cheng, G., \& Chau, J. (2016). Exploring the relationships between learning styles, online participation, learning achievement and course satisfaction: An empirical study of a blended learning course. British Journal of Educational Technology, 47(2), 257-278.

Chin, C., \& Brown, D.E. (2000). Learning in science: A comparison of deep and surface approaches. Journal of Research in Science Teaching, 37(2), 109-138.

Christensen, L., \& Evamy, S. (2011). MAPs to success: Improving the first year experience of alternative entry mature age students. The International Journal of the First Year in Higher Education, 2(2), 35-48.

Creswell, J.W., Clark, V.L., Gutmann, M., \& Hanson, W. (2003). Advanced mixed methods research designs. Handbook on Mixed Methods in the Behavioral and Social Sciences. In: Tashakkori, A., \& Teddlie, C., (Eds.), Designing and Conducting Mixed Methods Research. Thousand
Oaks, CA: Sage. pp. 209-240.

Çardak, Ç.S., \& Selvi, K. (2016). Increasing teacher candidates' ways of interaction and levels of learning through action research in a blended course. Computers in Human Behavior, 61, 488-506.

Dillenbourg, P., Baker, M., Blaye, A., \& O’Malley, C. (1996). The evolution of research on collaborative learning. In: Spada, E., \& Reiman, P., (Eds.), Learning in Humans and Machine: Towards an Interdisciplinary Learning Science. Oxford: Elsevier. pp. 189-211).

Ding, X., Niu, J., \& Han, Y. (2010). Research on distance education development in China. British Journal of Educational Technology, 41(4), 582-592.

Dziuban, C.D., Hartman, J.L., Cavanagh, T.B., \& Moskal, P.D. (2011). Blended courses as drivers of institutional transformation. In Kitchenham, A., (Ed.), Blended Learning Across Disciplines: Models for Implementation. Hershey PA: IGI Global. pp. 17-36.

Entwistle, N., \& Peterson, E.R. (2004). Learning styles and approaches to studying. In: Spielberger, C., (Ed.), Encyclopedia of Applied Psychology. New York: Academic Press. pp. 537-542.

Fraenkel, J.R., Wallen, N.E., \& Hyun, H.H. (2012). How to Design and Evaluate Research in Education. $8^{\text {th }}$ ed. New York: McGram-Hill Companies.

Garrison, D.R., \& Vaughan, N.D. (2008). Blended Learning in Higher Education: Framework, Principles, and Guidelines. San Francisco: Jossey-Bass.

Geer, R. (2009). Strategies for blended approaches in teacher education. In: Stacey, E., \& Gerbic, P., (Eds.), Effective Blended Learning Practices: Evidence-Based Perspectives in ICT-Facilitated Education. Hershey, PA: Information Science Reference. pp. 39-59.

Gholami, V., \& Moghaddam, M.M. (2013). The effect of weekly quizzes on students' final achievement score. International Journal of Modern Education and Computer Science, 5(1), 36-41.

Gil, O.P., \& Garcia, F.A. (2011). Blended learning revisited: How it brought engagement and interaction into and beyond the classroom. In: Kitchenham, A., (Ed.), Blended Learning Across Disciplines: Models for Implementation. Hershey, PA: IGI Global. pp. 58-72.

Graham, C.R. (2006). Blended learning systems: definition, current trends, and future directions. In: Bonk, C.J., \& Graham, C.R., (Eds.), The Handbook of Blended Learning: Global Perspectives and Local Designs. USA: Pfeiffer. pp. 3-21.

Graham, C.R., \& Robinson, R. (2007). Realizing the transformation potential of blended learning: Comparing cases of transforming blends and enhancing blends in higher education. In: Picciano, A.G., \& Dziuban, C.D., (Eds.), Blended Learning: Research Perspectives. Needham, MA: Sloan. pp. 83-110.

Gröber, S., Vetter, M., Eckert, B., \& Jodl, H.J. (2007). Experimenting from a distance-remotely controlled laboratory (RCL). European Journal of Physics, 28(3), 127-141.

Haberyan, K.A. (2003). Do weekly quizzes improve student performance on general biology exams? American Biology Teacher, 65(2), 110-114.

Harris, A.L., \& Rea, A. (2009). Web 2.0 and virtual world technologies: A growing impact on IS education. Journal of Information Systems Education, 20(2), 137-144.

Harry, K., John, M., \& Keegan, D. (1993). Distance Education: New perspective. London: Routledge.

Hattie, J., \& Gan, M. (2011). Instruction based on feedback. In: Alexander, P., \& Mayer, R.E., (Eds.), Handbook of Research on Learning and Instruction. New York: Routledge. pp. 249-271.

James, A.O., \& Folorunso, A.M. (2012). Effect of feedback and remediation on students' achievement in junior secondary school mathematics. International Education Studies, 5(5), 153-162.

Kolowich, S. (2010). The Human Element. Available from: https://www. insidehighered.com/news/2010/03/29/1ms.

Kuyatt, B.L., \& Baker, J.D. (2014). Human anatomy software use in traditional and online anatomy laboratory classes: Student-perceived learning benefits. Journal of College Science Teaching, 43(5), 14-19.

Lee, Y.C., Lau, K.C., \& Yip, V.W.Y. (2016). Blended learning for building student-teachers' capacity to learn and teach science-related interdisciplinary subjects: The case of Hong Kong. Asian Association of Open Universities Journal, 11(2), 166-181.

Leong, P. (2011). Role of social presence and cognitive absorption in online 
learning environments. Distance Education, 32(1), 5-28.

Lorenzo, G., \& Moore, J. (2002). The Sloan Consortium Report to the Nation: Five Pillars of Quality Online Education. Available from: https:// www.immagic.com/eLibrary/ARCHIVES/GENERAL/SLOANCUS/ S021106L.pdf

Luehmann, A.L., \& Frink, J. (2012). Web 2.0 technologies, new media literacies, and science education: Exploring the potential to transform. In: Fraser, B.J., Tobin, K.G., \& McRobbie, C.J., (Eds.), Second International Handbook of Science Education. Netherlands: Springer. pp. 823-837.

Luehmann, A.L., \& Tinelli, L. (2008). Teacher professional identity development with social networking technologies: Learning reform through blogging. Educational Media International, 45(4), 323-333.

Marquis, C. (2004). WebCT Survey Discovers a Blend of Online Learning and Classroom-Based Teaching is the Most Effective form of Learning Today. Available from: http://www.webct.com/

Mawn, M.V., Carrico, P., Charuk, K., Stote, K.S., \& Lawrence, B. (2011). Hands-on and online: Scientific explorations through distance learning. Open Learning, 26(2), 135-146.

Milli Eğitim Bakanlığı (MONE). (2013). İlköğretim Fen ve Teknoloji Dersi (6, 7 ve 8. Sinıflar) Öğretim Programı. Ankara: MEB Yayınları.

Morice, J., Michinov, N., Delaval, M., Sideridou, A., \& Ferrières, V. (2015). Comparing the effectiveness of peer instruction to individual learning during a chromatography course. Journal of Computer Assisted Learning, 31(6), 722-733.

Olympiou, G., \& Zacharia, Z.C. (2012). Blending physical and virtual manipulatives: An effort to improve students' conceptual understanding through science laboratory experimentation. Science Education, 96(1), 21-47.

Ottander, C., \& Grelsson, G. (2006). Laboratory work: The teachers' perspective. Journal of Biological Education, 40(3), 113-118.
Pelliccione, L., \& Broadley, T. (2010). R U there yet? Using virtual classrooms to transform teaching practice. In: Steel, C., Keppell, M., Gerbic, P. \& Housego, S. (Eds.), Curriculum, Technology and Transformation for an Unknown Future, Ascilite Conference Proceedings 2010, 5-8 December 2010, Sydney, Australia. pp. 749-760.

Rivera, J.H. (2016). Science-based laboratory comprehension: An examination of effective practices within traditional, online and blended learning environments. Open Learning: The Journal of Open, Distance and e-learning, 31(3), 209-218.

Scott, D.F. (2015). Decompression Syndromes: The Bends, Available from: https://www.emedicinehealth.com/decompression_syndromes_the bends/article_em.htm.

Trpkovska, M.A. (2011). A Study of Student Perceptions on Blended and Online Learning over Traditional Classroom Instruction at South East European University. Paper Presented at the Information Technology Interfaces (ITI), Proceedings of the ITI $201133^{\text {rd }}$ International Conference. pp. 245-250.

Van der Kleij, F.M., Feskens, R.C., \& Eggen, T.J. (2015). Effects of feedback in a computer-based learning environment on students' learning outcomes: A meta analysis. Review of Educational Research, 85(4), 475-511.

Van Tryon, P.J.S., \& Bishop, M.J. (2009). Theoretical foundations for enhancing social connectedness in online learning environments. Distance Education, 30(3), 291-315.

Wilder, D.A., Flood, W.A., \& Stromsnes, W. (2001). The use of random extra credit quizzes to increase student attendance. Journal of Instructional Psychology, 28(2), 117-117.

Zarei, A.A. (2008). On the Learnability of three categories of Idioms by Iranian EFL learners. Journal of Humanities of the University of Kerman, 2(2), 82-100. 